\title{
Long Term Performance of Islamic Share Price for Initial Public Offerings (IPOs) in Malaysia: Evidence from Sharia-Compliant Companies Listed on the Malaysian Stock Exchange (2006-2010)
}

\author{
${ }^{1}$ Nashirah Binti Abu Bakar, ${ }^{2}$ Sofian Rosbi \\ ${ }^{1}$ Islamic Business School, College of Business, Universiti Utara Malaysia, Kedah, Malaysia \\ ${ }^{2}$ Universiti Malaysia Perlis, Perlis, Malaysia
}

\begin{abstract}
The objective of this study is to investigate the long-term (one to three year) performance of initial public offerings (IPOs) for sharia-compliant companies listed on the Malaysian Stock Exchange (MSE) for the period from 2006 till 2010. This study examines why some IPOs companies have a positive, and some IPOs companies have a negative long-term cumulative abnormal return (CAR). KLCI index is used as a benchmark for measuring long-term performance of IPOs for sharia-compliant companies. The empirical results show that the long-term performances for sharia-compliant companies are performed better (16.81 percent) than their benchmark for CAR equal-weight and the result for CAR value-weight show a slightly outperformed their benchmark ( -0.07 percent). The results also indicate that CAR for equal-weight and value-weight of IPOs for sharia-compliant companies are significantly higher over performing by 14.58 percent and 4.11 percent respectively in the year 2006. While the results in 2007 ( -1.34 percent) and 2008 (-3.43 percent) for value-weight are underperformed. This study also found that the underpricing, offer price, offer size, market type, trading/service industry, consumer product industry, property industry and REIT industry were statistically significant.
\end{abstract}

Keywords: Islamic Finance, Sharia-Compliant Companies, Initial Public Offerings (IPOs), Long Term Performance, Cumulative Abnormal Return (CAR)

\section{Introduction}

Islamic banking introduced in Malaysia in the year of $1982^{1}$, the concept of Islamic finance has been raised ${ }^{2}$. On May 2013 , the market capitalization of sharia-compliant securities was valued at $\mathrm{MYR}^{3} 1.017 \mathrm{tln}$ or $63 \%$ out of a total market capitalization of about MYR1.6t $\ln ^{4}$. IPOs for sharia-compliant companies are seen as a change for Muslim companies and investors to participant in Islamic investments. The high demand for sharia-compliant companies interacts with more IPOs companies to list shares on the sharia board. Figure 1 shows the total of the Sharia-compliant companies, and Figure 2 demonstrates the IPOs for sharia-compliant companies listed on the MSE.

\footnotetext{
${ }^{1}$ Bank Islam Malaysia Berhad (BIMB) is the first Islamic Bank in Malaysia, established in 1982.

${ }^{2}$ Other developments of Islamic finance included: Takaful (Insurance) Islamic Capital Market, and Sukuk (bond), among others.

${ }^{3}$ MYR is Malaysian Currency

${ }^{4}$ Sharia Screening Methodology: Adopting Two-tier Quantitative Approach by Malaysian International Islamic Financial Centre (MIFC) 31 October 2013 


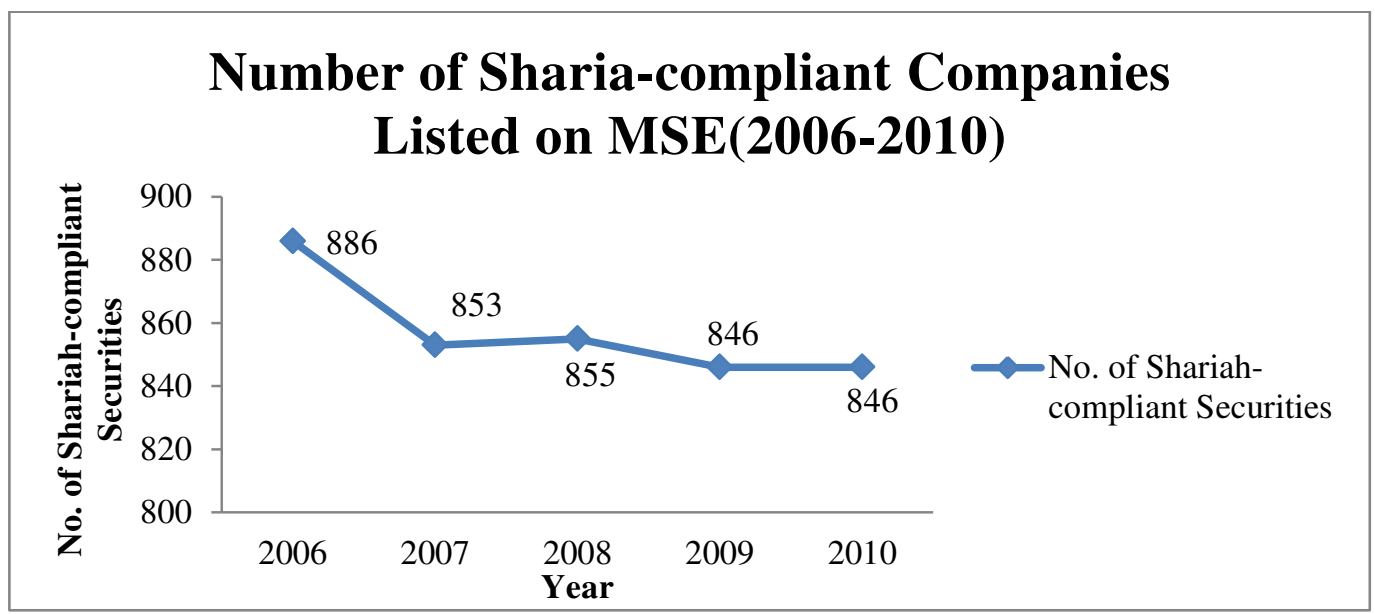

Figure 1: Total Number of Sharia-compliant Companies (2006-2010)

Sources: Sharia Advisory Council of the Securities Commission, Malaysia

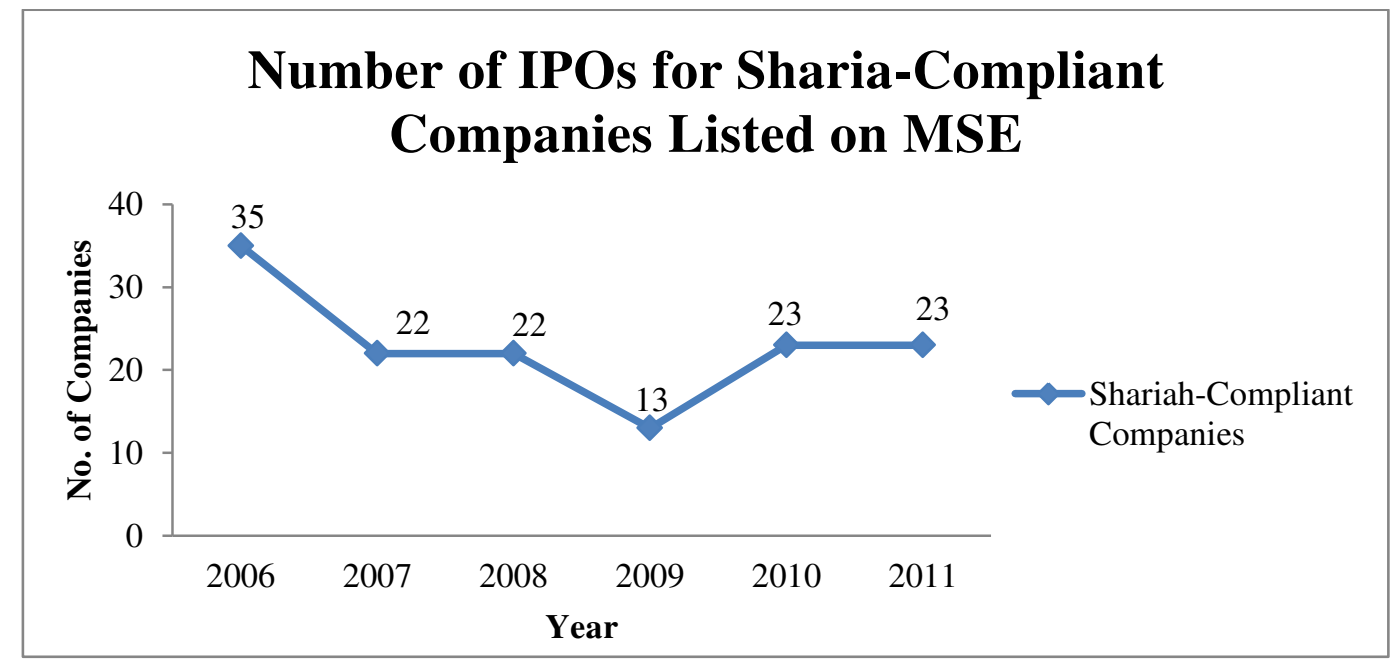

Figure 2: IPOs for Sharia-Compliant Companies

Sources: Malaysian Stock Exchange (MSE)

Despite numerous empirical studies on the long-term performance of IPOs on the Malaysian market (Paudyal, et al., 1998; Ahmad Zaluki, et al., 2007; How et al., 2011) no prior academic work has documented the long-term performance of IPOs for sharia-compliant companies. Most of the previous studies are combined the sharia-compliant and non-sharia-compliant companies. This study tries to fill this gap by investigated either IPOs for sharia-compliant companies are over performance or underperformance their benchmark.

The sharia board is established to fulfill the needed of Islamic investors and companies in Malaysia and the rest of the world. The main feature of a sharia-compliant board is to provide an investment in line with Islamic law. A shariacompliant board must represent an assertion of Islamic law where the market should be free from the prohibited element such as usury (riba), gambling (maisir), and uncertainties (gharar).

In 1995, The Sharia Advisory Council (SAC) of Securities Commission of Malaysia established the methods to undertake Sharia screening process for companies to list on the MSE. The methods comprise quantitative and qualitative assessments. At the end of November 2013, the SAC revised the quantitative evaluation that applied to the business activity benchmark and the newly introduced financial ratio benchmarks while at the same time maintaining a 
Nashirah Binti Abu Bakar, Sofian Rosbi

Long Term Performance of Islamic Share Price for Initial Public Offerings (IPOs) in Malaysia: Evidence

from Sharia-Compliant Companies Listed on the Malaysian Stock Exchange (2006-2010)

qualitative assessment. The following diagram is of the quantitative and qualitative methods implement by SAC after revision:

\section{Stage 1: Quantitative Method}

\section{Business Activity Benchmarks}

The $5 \%$ benchmark would be applicable to the following business activities:

- Conventional banking

- Conventional insurance

- Gambling

- Non-halal food and beverages

- Interest income from conventional accounts and instruments

- Other activities deemed non-compliant according to sharia

The $20 \%$ benchmark would be applicable to the following activities:

- $\quad$ Share trading

- $\quad$ Stockbroking business

- Other activities deemed non-compliant according to sharia

\section{Financial Ratio Benchmarks}

The financial ratios applied are as follows:

i. Cash over Total Assets

Cash will only include cash placed in conventional accounts and instruments, whereas cash placed in Islamic accounts and instruments will be excluded from the calculation.

ii. Debt over Total Assets

Debt will only include interest-bearing debt whereas Islamic debt/financing or sukuk will be excluded from the calculation. Both ratios that are intended to measure riba and riba-based elements within a company's balance sheet, must be lower than $33 \%$
This

company is

listed on

Non Sharia

Board

Company is

not comply

with Sharia

requirements

Company is comply with Sharia requirements

This company is listed on Non Sharia Board

1. Public perception

2. Image of the company

Hence, if a security passed in the quantitative stage, it could be deemed as non-sharia-compliant if it fails this stage. For example, negative public perception or image of the IPOs companies.

Company is comply with Sharia requirements

Accept to list shares on the Sharia Board of the MSE

Diagram 1: Overview of the screening process implement by Sharia Advisory Council of Securities Commission of Malaysia 
The purpose of this paper is looking for the long-term performance of IPOs for sharia-compliant companies by matching into FTSE Bursa Malaysia market index. This study contributes to the literature on the long-term performance of IPOs for sharia-compliant companies by looking on the Malaysian IPOs market from 2006 till 2010.

\section{Literature Review}

Many theories explain the long-term performance of IPOs. In measuring the long-term performance of IPOs, IPOs are compared with benchmarks. Several benchmarks are used as follows: market index, portfolios of firms such as bookto-market ratio, size, or industry. In the long-term performance of IPOs, there are two ways to measure return: cumulative abnormal return (CAR) and buy-and-hold return (BHAR). CAR is the total monthly abnormal return. Abnormal return is monthly excess returns between IPOs companies and the benchmark. BHAR is an excess return that investors earn if they hold IPOs shares for a certain period. Therefore, if investors hold the IPOs shares for one year, BHAR is the excess return that investors receive from one year.

Various studies have investigated long-term performance of IPOs markets found that IPOs underperformed their benchmarks. Ritter (1991) examined long-term performance of IPOs in the United States and found they significantly underperformed their benchmarks using CAR and BHAR methods. Carter et al. (1998) also found IPOs stocks were underperformed relative to the market over a three-year holding period and less severe for IPOs handled by underwriters with more prestige. Chan, et al. (2003) has also reported the same results in China. They found IPOs in China also slightly underperformed. While, Lee, et al. (1996) reported that Australian IPOs significantly underperformed market movements in the three-year period after list. Drobetz et al. (2005) indicated that long-term performance of Swiss IPOs and found that IPOs underperformed their benchmarks. Levis (1993) found the long-term performance of IPOs in the United Kingdom underperformed using the CAR method. The same result was also reported when BHAR was used. Cai and Wei (1997) measured IPOs performance in Japan and found that IPOs underperformed their benchmarks. Kooli and Suret (2004) investigated long-term performance in Canada. Using data from 1991 to 1998 , they found that IPOs underperformed.

Drobetz, et al. (2005) found long run underperformance from IPOs firms as they tended to be small firms that used a small capitalization index as the benchmark. This study investigated IPOs companies in Switzerland using data from 1983 to 2000. Therefore, underperformed of long-term IPOs were observed in various countries. However, Kim, et al. (1995) found that long-term performance of IPOs was observed to be better in Korea with an excess return of IPOs that ranged from $80.63 \%$ to $91.59 \%$. Barber and Lyon (1997) argued that long-term abnormal return should be calculated as the long-term BHAR for two reasons. The first reason is that CAR is a biased predictor of BHAR. This problem at its worst can lead to incorrect inferences. For example, a sample of the firms that all have zero annual buys and hold abnormal returns calculated relative to a market benchmark have a corresponding 12-month mean cumulative abnormal return of $+5 \%$ on average. In this sampling situation, researchers who restrict their analysis to cumulative abnormal returns ignore the analysis of buy and hold; abnormal returns could conceivably conclude that the sample in question earned long run abnormal returns when in fact it did not. In a random sample, researchers can draw different inferences using CAR in lieu of BHAR in roughly $4 \%$ of all sampling situations.

The second reason is that even if the inference based on CAR is correct, the documented magnitude does not correspond to the value of investing in the average or median sample firm relative to an appropriate benchmark over the horizon of interest. This is precisely the objective of long-term event studies of stock returns. Gao and Jain (2011) found weak evidence of superior long-run investment performance on the part of founder CEOs who led IPOs companies. The study also found that high technology IPOs companies have consistent evidence to indicate that founder CEOs who lead companies provide significantly higher long-run return relative to no-founder CEO led companies.

How, et al. (2011) found robust results that companies, which initiated a dividend, perform significantly better up to five years after the initiation date in Australia. Bessler and Thies (2007) found that the subsequent financing activity on the equity market is the most important factor in determining the future performance of IPOs in Germany. 
Su and Bangassa (2011) examined IPOs underpricing and long-run IPOs performance of Chinese IPOs. They found that a little influence of underwriter reputation on the level of IPOs underpricing, but a significant positive relationship between underwriter reputation and the level of IPO's long-run performance. Although the significantly negative threeyear market-adjusted buy-and-hold abnormal return suggested a potential loss to investors who hold Chinese IPOs long-term, investing in IPOs managed by more prestigious underwriters helps mitigate losses.

This paper focuses on the long-term performance of IPOs markets in Malaysia and found evidence for the long-term performance of IPOs performed better long-term (How, et al., 2007). Ahmad-Zaluki et al. (2007) found that significant over performance for equally weighted event time CARs and buy-and-hold returns using two market benchmarks, though not for value-weighted returns or using a matched company benchmarks. The significant abnormal performance also disappeared under the calendar-time approach using the Fama-French, three-factor model. While the long run performance of main- and second-board IPOs do not differ from the years of listing, issue proceeds, and initial returns were found to be performance-related.

Corhay, et al. (2002) found IPOs tend to outperform the market with a positive CAR of $41.7 \%$ over three years from the listing day. Jelic, et al. (2001) examined the financial performance of Malaysian IPOs from 1980 to 1995 . The results suggest extremely high and statistically significant initial premiums and positive and statistically significant long-term up to 3 years after listing. The findings for long-term returns contradict the consensus of the IPOs literature that documents a significant negative long-term performance. This result indicates a negative association of upward bias in management earnings forecast with an IPOs performance from the first 12 months after the IPOs.

While Paudyal et al. (1998) found that IPOs underwritten by reputed underwriters are significantly better long-term investments when compared to IPOs underwritten by less reputed underwriters. Ahmad Zaluki and Boon Kect (2012) provided evidence on short- and long-run investment performance of Malaysian IPOs that are listed on the MESDAQ market. In line with post-Malaysian studies, the results of the raw and market-adjusted initial return show that IPOs companies are significantly underpriced in the short-run. However, in the long-run, the CAR and BHAR methods reveal that these companies underperformed the market. This result concerns the long-run performance in contrast with the results observed by previous Malaysian studies using a sample of companies listed on the mainboard and/or second board. However, they are consistent with the results reported in other countries. This study found that companies in the technology sector issued during a hot issue period, and underpriced IPOs performed less well in the long-run, which supports the fad hypothesis of long-run underperformance. This study suggested that investors who purchase IPOs shares on the MESDAQ market gain high positive returns in the short-run but do not fare well in the long-run. This study provides new information to investors when choosing IPOs listed on the MSE. Table 1 summarizes others studies regarding long-term performance of IPOs.

Table 1: Summarizing of long-term performance of IPOs worldwide

\begin{tabular}{|c|l|l|l|}
\hline Country & \multicolumn{1}{|c|}{ Period of Study } & \multicolumn{1}{|c|}{ Long-term performance of IPOs } & \multicolumn{1}{|c|}{ Authors } \\
\hline United Kingdom & $1991-1995$ & Underperformed & Goergen, et al. (2007) \\
\hline China & $1993-1998$ & $\begin{array}{l}\bullet \text { A-shares: underperformed } \\
\text { B-Shares: outperformed }\end{array}$ & Chan, et al. (2003) \\
\hline Japan & $1998-2001$ & Underperformed & Kirkulak (2008) \\
\hline Taiwan & $1991-2002$ & Outperformed & Chen, et al. (2010) \\
\hline Turkey & $1990-1997$ & Outperformed & Durukan (2002) \\
\hline
\end{tabular}

\section{Research Methodology}

This study evaluates the long-term performance of IPOs for sharia-compliant companies by computing CAR for 1-36 months after listing initial exclusionary returns. To measure the long-term performance of IPOs for Sharia-compliant companies, this study uses the FTSE Bursa Malaysia Market Index as a benchmark. The daily IPOs closing prices are taken from the Yahoo finance website. The total IPOs shares issued from 2006-2010 was 115 IPOs for sharia- 
compliant companies. After deducting IPOs with imperfect information, this study used 74 IPOs for sharia-compliant companies that meet the following criteria: (i) the companies are listed on the MSE for 3 years; (ii) for companies with imperfect information must be excluded from this study; and (iii) this study used closing pricing to calculate CAR. Return is defined as the daily return on the closing price listed on the MSE. A month is defined as following 20trading-day periods. Thus, month 1 consists of event day 1-20. Month 2 consists of event $21-41$ and, continuously, to month 36.

To get a three-year CAR, the abnormal returns for each month, for a 36-month period are calculated. Firstly, this study calculated return for IPOs for sharia-compliant companies used the following formula:

Where,

$$
R_{i t}=\frac{C_{x i}-C_{x i-1}}{C_{x i-1}}
$$

$R_{i t}$ : Return for company i from period $\mathrm{t}$

$C_{x i}$ : Today closing price for company $\mathrm{i}$

$C_{x i-1}$ : Yesterday closing price for company i

Secondly, this study calculated the return for the market index used the following formula. This study used FTSE Bursa Malaysia market index as a benchmark.

Where,

$$
R_{m t}=\frac{C_{m i}-C_{m i-1}}{C_{m i-1}}
$$

$R_{m t}$ : Return for FTSE Bursa Malaysia market index from period t

$C_{m i}$ : Today closing price for FTSE Bursa Malaysia market index

$C_{m i-1}$ : Yesterday closing price for FTSE Bursa Malaysia market index

Third, daily abnormal return $\left(A R_{i t}\right)$ is calculated using this formula:

Where,

$$
A R_{i t}=R_{i t}-R_{m t}
$$

$A R_{i t}$ : Abnormal return for company i from period $\mathrm{t}$

$R_{i t}$ : Return for company $\mathrm{i}$ from period $\mathrm{t}$

$R_{m t}$ : Return for FTSE Bursa Malaysia market index (benchmark) from period t

Then, to get an average abnormal return $\left(R_{t}\right)$ in a month, $A R_{i t}$ is averaged.

$$
A R_{t m}=\frac{\sum_{t=1}^{20} A R_{i t}}{N}
$$

Where,

$A R_{t m}$ : Average $A R_{i t}$ in month 1 to month 36

$\sum_{t=1}^{20} A R_{i t}$ : Sum of $A R_{i t}$ for day 1 to day 20

$\mathrm{N}$ : Number of trading days in one month

Therefore, to get an average abnormal return $\left(\boldsymbol{A} \boldsymbol{R}_{\boldsymbol{i t}}\right)$ is multiplied by the weight for the company $\mathrm{i}$.

$$
\boldsymbol{R}_{t}=\sum_{t=1}^{n_{t}} w_{i} * A R_{i t}
$$

Where,

$R_{t}$ : Average abnormal return from period $\mathrm{t}$

$A R_{i t}$ : Abnormal return for company $\mathrm{i}$ from period $\mathrm{t}$

$w_{i}$ : Weight for company $\mathrm{i}$

$n_{t}$ : Number of companies from period $\mathrm{t}$

Two types of weight are used in this study; equal-weight (EW) and value-weight (VW).

\section{1. $\mathrm{EW}=1 / n_{t}$}


$\mathrm{n}_{\mathrm{t}}$ : Number of IPOs companies for sharia-compliant companies issues from period $\mathrm{t}$

2. $\mathrm{VW}=\frac{M V_{i}}{\sum_{i=1}^{n_{t}} M V_{i}}$

Where,

$M V_{i}$ : Market value of company i.

Therefore, to calculate three-year CAR from month 1 to months $36 R_{t}$ is summed from period 1 to 36 as follows:

$$
\operatorname{CAR}_{1,36}=\sum_{t=1}^{36} R_{t}
$$

Where,

$C A R_{1,36}$ : Cumulative abnormal return from month-1 to month-36

$R_{t}$ : Average abnormal return

To quantify the role of the explanatory variables on the long-term performance of IPOs for Sharia-compliant companies, this study performs a multiple linear regression, which is estimated by the following equation (for equal weight):

$$
\begin{aligned}
& L T_{E W}=\alpha_{\mathrm{i}}+\beta_{1}\left(U P_{i}\right)+\beta_{2}\left(O P_{i}\right)+\beta_{3}\left(O S_{i}\right)+\beta_{4}\left(C_{i}\right)+\beta_{5}\left(\mathbf{O S}_{i}\right)+\beta_{6}\left(R_{i}\right)+\beta_{7}\left(U_{R_{i}}\right)+\beta_{8}\left(\mathrm{TM}_{\mathrm{i}}\right) \\
& +\beta_{9}\left(T_{i}\right)+\beta_{10}\left(E_{i}\right)+\beta_{11}\left(R_{10 E}\right)+\beta_{12}\left(I A_{i}\right)+\varepsilon_{i}
\end{aligned}
$$

Where,

$L T_{E W}$ : Cumulative abnormal return (CAR) equal-weight for sharia-compliant companies.

$U P_{i}$ : Underpricing of company $i$

$\mathrm{OP}_{\mathrm{i}}$ : Offer price of company $i$

$\mathrm{OS}_{\mathrm{i}}$ : Offer size of company $i$

$\mathrm{CA}_{\mathrm{i}}$ : Company age of company $\mathrm{i}$

$\mathrm{OS}_{\mathrm{i}}$ : Oversubscription of company $\mathrm{i}$

$\mathrm{R}_{\mathrm{i}}$ : Risk of company $\mathrm{i}$

$\mathrm{UR}_{\mathrm{i}}$ : Underwriter reputation of company $i$

$\mathrm{TM}_{\mathrm{i}}$ : Type of market of company $\mathrm{i}$

$\mathrm{TI}_{\mathrm{i}}$ : Type of industry of company $\mathrm{i}$

EC: Economic condition of company $i$

ROE: Return on equity of company $i$

$I A_{i}$ : Information Asymmetric (1, if the companies disseminate investment information (investors' relation) through the internet (website). 0 , otherwise.)

$\varepsilon_{\mathrm{i}}$ : Others factor of company i

The following equation is the multiple linear regression analysis for Cumulative Abnormal Return (CAR) for value-weight:

$$
\begin{aligned}
& L T_{V W}=\alpha_{i}+\beta_{1}\left(U P_{i}\right)+\beta_{2}\left(O P_{i}\right)+\beta_{3}\left(O_{i}\right)+\beta_{4}\left(C_{i}\right)+\beta_{5}\left(\mathbf{O S}_{i}\right)+\beta_{6}\left(R_{i}\right)+\beta_{7}\left(U_{R_{i}}\right)+\beta_{8}\left(\mathrm{TM}_{\mathrm{i}}\right) \\
& +\beta_{9}\left(\mathrm{TI}_{\mathrm{i}}\right)+\beta_{10}\left(\mathrm{EC}_{\mathrm{i}}\right)+\beta_{11}\left(\mathrm{ROE}_{\mathrm{i}}\right)+\beta_{12}\left(I A_{i}\right)+\varepsilon_{\mathrm{i}}
\end{aligned}
$$

Where,

$L T_{V W}$ : Cumulative abnormal return (CAR) value-weight for sharia-compliant companies.

$U P_{i}$ : Underpricing of company $i$

$O P_{i}$ : Offer price of company $i$

$\mathrm{OS}_{\mathrm{i}}$ : Offer size of company i

$\mathrm{CA}_{\mathrm{i}}$ : Company age of company $\mathrm{i}$

$\mathrm{OS}_{\mathrm{i}}$ : Oversubscription of company $\mathrm{i}$

$\mathrm{R}_{\mathrm{i}}$ : Risk of company $\mathrm{i}$

$\mathrm{UR}_{\mathrm{i}}$ : Underwriter reputation of company $\mathrm{i}$

$\mathrm{TM}_{\mathrm{i}}$ : Type of market of company $\mathrm{i}$

$\mathrm{TI}_{\mathrm{i}}$ : Type of industry of company $\mathrm{i}$ 
Nashirah Binti Abu Bakar, Sofian Rosbi

Long Term Performance of Islamic Share Price for Initial Public Offerings (IPOs) in Malaysia: Evidence from Sharia-Compliant Companies Listed on the Malaysian Stock Exchange (2006-2010)

EC: Economic condition of company i

ROE: Return on equity of company $i$

$I A_{i}$ : Information Asymmetric (1, if the companies disseminate investment information (investors' relation) through the internet (website). 0, otherwise.)

$\varepsilon_{\mathrm{i}}$ : Others factor of company i $\backslash$

Table 2 summarizes the definitions of explanatory variables.

Table 2: Definitions of Explanatory Variablesz

\begin{tabular}{|c|c|c|}
\hline No. & $\begin{array}{l}\text { Explanatory } \\
\text { Variables }\end{array}$ & Definitions \\
\hline 1 & Offer price (OP) & Offer price per share (retail) in Malaysian Dollar (RM) ${ }^{5}$. \\
\hline 2 & Offer size (OS) & The number of shares offered (unit) multiplied by par value (RM) per share. \\
\hline 3 & Company age (CA) & $\begin{array}{l}\text { Company age computed from the date (year) of incorporation to the date (year) of listing on } \\
\text { the MSE. }\end{array}$ \\
\hline 4 & Company age (CA) & $\begin{array}{l}\text { Demand for IPOs shares exceeded than a total number of IPOs shares issued. For example, if } \\
\text { an IPOs offers two million shares but the applications are for } 20 \text { million shares, then the } \\
\text { times of oversubscription rate is } 10 \text {. }\end{array}$ \\
\hline 5 & Risk (R) & $\begin{array}{l}\text { Using the method found in Rahim and Yong (2010), this study calculated risk as the } \\
\text { reciprocal of the IPOs offer price that is: } \\
\text { risk }=\frac{1}{\mathrm{OF}_{\mathrm{i}}} \\
\text { where, } \\
\mathrm{OF}_{\mathrm{i}}=\text { offering price for company } \mathrm{i} \text {. }\end{array}$ \\
\hline 6 & $\begin{array}{l}\text { Underwriter } \\
\text { reputation (UR) }\end{array}$ & $\begin{array}{l}1 \text { if high underwriter reputation. High underwriter reputation is the first and second highest } \\
\text { number of IPOs managed by an underwriter from of study, } 0 \text { otherwise. }\end{array}$ \\
\hline 7 & $\begin{array}{l}\begin{array}{l}\text { Types of market } \\
(\mathrm{TM})\end{array} \\
\end{array}$ & 1 if $\mathrm{ACE}^{6}$ The market, 0 main ${ }^{7}$ market. \\
\hline 8 & $\begin{array}{l}\text { Types of industry } \\
\text { (TI): } \\
\text { 1. Property (PR) } \\
\text { 2. Technology (T) } \\
\text { 3. Plantation (PL) } \\
\text { 4. Trading/Service } \\
\text { (T_S) } \\
\text { 5. Consumer } \\
\text { Product (CP) } \\
\text { 6. Industrial Product } \\
\text { (IP) } \\
\text { 7. Infrastructure } \\
\text { Project Cos.(IPC) } \\
\text { 8. Construction (C) } \\
\text { 9. Real Estate } \\
\text { Investment Trusts } \\
\text { (REITs) }\end{array}$ & $\begin{array}{l}1 \text { if property industry, } 0 \text { otherwise } \\
1 \text { if technology industry, } 0 \text { otherwise } \\
1 \text { if plantation, } 0 \text { otherwise } \\
1 \text { if trading/service, } 0 \text { otherwise } \\
1 \text { if consumer product, } 0 \text { otherwise } \\
1 \text { if industrial product, } 0 \text { otherwise } \\
1 \text { if infrastructure project cos., } 0 \text { otherwise } \\
1 \text { if construction, } 0 \text { otherwise } \\
1 \text { if real estate investment trusts, } 0 \text { otherwise }\end{array}$ \\
\hline 9 & $\begin{array}{l}\text { Economic } \text { Condition } \\
\text { (EC) }\end{array}$ & $\begin{array}{l}1 \text { if the IPOs companies issues share from the sub-prime crisis (happened on December } \\
2007 \text { - June 2009), } \\
0 \text { otherwise. }\end{array}$ \\
\hline 10 & $\begin{array}{lll}\text { Return on } & \text { Equity } \\
\text { (ROE) } & & \end{array}$ & ROE is cited from Bloomberg BusinessWeek. Cited in 2014. \\
\hline
\end{tabular}

${ }^{5}$ The Malaysian dollar (RM) is the Malaysian currency.

${ }^{6} \mathrm{ACE}$ market is provided for the excellent growth companies.

${ }^{7}$ Main market is provided for the companies with sizable business. 


\section{Results}

The results are presented in two parts. Part 1 presents the results for CAR and part 2 presents the results as concerns the Pearson correlation analysis and multiple linear regression analysis for long-term performance of IPOs.

\subsection{Cumulative Abnormal Return (CAR)}

Table 3 reports the results of the three-year CAR for sharia-compliant companies. The result from 2006 to 2010 for CAR equal-weight for sharia-compliant companies was $16.81 \%$ and is statistically significant. However, the result for CAR value-weight was $-0.07 \%$ and was found to be insignificant at a level of significance. The results show that the long-term performance for sharia-compliant companies has performed better (16.81\%) than the benchmarks for CAR equal-weight. The results of the CAR value-weight were shown to slightly outperform the benchmarks $(-0.07 \%)$.

Several theories have been built to explain the long-term performance such as the divergence of opinion theory and window of opportunities theory. Miller (1977) indicated that all investors were assumed to have identical estimates of expected returns and the probability distribution of returns from all securities. However, it is implausible to assume that although the future is very uncertain and forecasts are difficult to make, that somehow everyone makes identical estimates of the returns and risks from every security. Therefore, only investors with high estimation were willing to buy IPOs shares.

Another theory to explain long-term performance was the window of opportunities. According to this theory, companies will go public when investors can buy an IPOs share. For example from a "hot issue" market, companies are willing to go public because the demands from investors are high. Ritter (1984) found that from the "hot issue" market in 1980 in the US was driven by the natural resources industry boom. Therefore, investors were willing to buy IPOs shares from this kind of market.

Table 3: Yearly Cumulative Abnormal Return (CAR)

\begin{tabular}{|c|c|c|}
\hline \multirow{2}{*}{ Year } & \multicolumn{2}{|c|}{ Sharia-Compliant Companies } \\
\cline { 2 - 3 } & CAR equal-weight & CAR value-weight \\
\hline 2006 & $14.58 \% *$ & $4.11 \%$ \\
\hline 2007 & $3.33 \%$ & $-1.34 \%$ \\
\hline 2008 & $3.84 \%$ & $-3.43 \%$ \\
\hline 2009 & $-3.27 \% * * *$ & $0.28 \%$ \\
\hline 2010 & $-1.67 \% * *$ & $0.31 \%$ \\
\hline $\mathbf{2 0 0 6 - 2 0 1 0}$ & $\mathbf{1 6 . 8 1 \% * *}$ & $\mathbf{- 0 . 0 7 \%}$ \\
\hline
\end{tabular}

*Indicates statistical significant at the $1 \%$ level,

** Indicates statistical significant at the 5\% level,

*** Indicates statistical significant at the $10 \%$ level

These findings show that the information regarding IPOs prices provided evidence that the market was efficient and, therefore, IPOs prices reflect the long-term performance of IPOs companies. Thus, if an investor is aware that significant performance of an IPOs will occur in future, they should adjust the current IPOs price by discounting IPOs offer price. Therefore, it seems that this adjustment can generate a positive return for long-term performance.

The results also show that 2006, 2009, and 2010 were found to be statistically significant at the level of significance, and the results for CAR value-weight found to be statistically insignificant at the level of significance.

\subsection{Pearson Correlation and Multiple Linear Regression Results.}

Table 4 provides the Pearson correlations for long-term performance of sharia-compliant companies for CAR equalweight among the variables, and none of the correlations was higher than 0.8 . The correlation coefficient of CAR 


\section{Nashirah Binti Abu Bakar, Sofian Rosbi \\ Long Term Performance of Islamic Share Price for Initial Public Offerings (IPOs) in Malaysia: Evidence \\ from Sharia-Compliant Companies Listed on the Malaysian Stock Exchange (2006-2010)}

equal-weight appears to be statistically significantly related to the offer price, oversubscription, risk, underwriter reputation, market type, technology industry, and consumer product industry. The correlation coefficient between risk factors and markets (0.713) appeared to be strongly significant.

Table 5 presents the results for the correlation of CAR value-weight. The correlation coefficient of CAR value-weight appeared to be statistically significant as related to the offer price, offer size, risk factors, underwriter reputation, market type, technology industry, and REIT industry. The correlation coefficient between a risk factor and market type (0.713) appeared to be strongly significant. These results also suggest that this variable played an important role in determining the performance of IPOs for sharia-compliant companies.

The next table (Table 6) shows the results for the explanatory variables on the CAR equal-weight for sharia-compliant companies listed on the MSE. It is important to highlight that underpricing, oversubscription, market type, consumer product industry, and ROE was statistically significant. The results for CAR value-weight (Table 7) indicate that underpricing, offer price, offer size, market type, trading/service industry, consumer product industry, property industry, and REIT industry were statistically significant.

Table 8 shows the R-square result for CAR equal-weight. The R-square was $59.4 \%$. This percentage shows that underpricing, oversubscription; market type, consumer product, and ROE can explain the 59.4\% variation for longterm performance of IPOs for sharia-compliant companies. The Durbin-Watson result was 1.751 and was within the acceptable range.

Table 9 presents the R-square for CAR value-weight. The R-square was $84.2 \%$. This percentage shows that underpricing, offer price, offer size, market type, trading/service, consumer product, property industry, and REIT industry can explain the $84.2 \%$ variation of long-term performance of IPOs for sharia-compliant companies. The Durbin-Watson result was 1.884 , which was within the acceptable range.

Table 10 and 11 present the F-value results for CAR equal-weight and CAR value-weight, respectively. The F-value for CAR equal-weight was 4.470 and CAR value-weight was 16.239 , which indicated that there is statistical significant between the dependent and independent variables.

Mixed results also found the relationship between determinant factors and long-term performance of IPOs for shariacompliant companies. The results of long-term performance of IPOs generated little evidence to support the working hypothesis, CAR equal-weight; underpricing, time of oversubscription, market type, consumer product industry, and ROE. Hence, the results of CAR value-weight appear to be consistent with the hypothesis. This study cannot confirm the findings from prior studies on the Malaysian market.

\section{Conclusion}

This research paper evaluates the long-term performance of IPOs and the impact of determinant factors on the longterm performance of IPOs for sharia-compliant companies is discussed. Firstly, regarding the methodology, the calculations are considering FTSE Bursa Malaysia Market Index as a benchmark. Then, this study found that IPOs for sharia-compliant companies outperformed when CAR equal-weight was used to measure long-term performance of IPOs for sharia-compliant companies. This result parallels previous studies regarding long-term performance of IPOs on the Malaysian market (How, et al., 2007; Ahmad-Zaluki and Goodacre, 2007; Paudyal, et al., 1998). The results of this paper point out that the use of equal- or value-weight returns typically led to different conclusions. Also, the result for CAR equal-weight was statistically significant while value-weight was insignificant.

Secondly, IPOs for sharia-compliant companies perform at least as good as their matches. The result shows that it is important to highlight that underpricing, over-subscription; market type, consumer product industry and ROE were statistically significant for CAR equal-weight. The results for CAR value-weight indicated that underpricing, offer price; offer size, market type, trading/service industry, consumer product industry, property industry, and REIT industry were statistically significant. The overconfidence of investors from the initial trading of IPOs has an impact on 


\section{Nashirah Binti Abu Bakar, Sofian Rosbi \\ Long Term Performance of Islamic Share Price for Initial Public Offerings (IPOs) in Malaysia: Evidence \\ from Sharia-Compliant Companies Listed on the Malaysian Stock Exchange (2006-2010)}

the long-term performance of IPOs for sharia-compliant companies. Therefore, investor loyalty for IPOs companies is important in determining the good performance of IPOs for earliest three-year trading on the stock exchange.

Finally, the important finding from this study is the performance of IPOs in Malaysia are associated with high underpricing from the initial trading on the stock exchange (i.e.: Dowson, 1987). However, this study found that high underpricing in the initial trading does not determine poor performance in the first 3 years after IPOs shares were issued. The study found that IPOs for sharia-compliant companies are comparable to or possibly performed better than the benchmarks. The results also show that in 2008, when the sub-prime crisis happened, the long-term performance of IPOs did not differ from the performance of the benchmarks. Therefore, it seems that even the average degree of IPOs underpricing was high and was not determined the poor long-term performance of the IPOs for sharia-compliant companies. As the conclusion, the long-term performance of Islamic share price for IPOs in Malaysian Companies during the year of 2006 until 2010 are comparable to or possibly performed better than the FTSE Bursa Malaysia Market Index.

\section{References}

- $\quad$ Ahmad-Zaluki, N. A, Campbell, K. and Goodacre, A. (2007) The Long Run Share Price Performance of Malaysian Initial Public Offerings (IPOs) Journal of Business and Accounting, Vol. 34, No. 1, pp. 78-110, CrossRef

- $\quad$ Ahmad-Zaluki, N.A. and Boon Kect, L., (2012) The investment performance of MESDAQ market Initial Public Offerings (IPOs) Asian Academy of Management Journal of Accounting and Finance, Vol. 8, No.1, pp. 1-23

- Barber, B. M., and Lyon, J. D. (1997) Detecting long-run abnormal stock returns: The empirical power and specification of test statistics. Journal of Finance Economics, 43, 341-372, $\underline{\text { CrossRef }}$

- $\quad$ Bessler, W. and Thies (2007) The long-run performance of initial public offerings in Germany, Managerial Finance, Vol. 33, No. 6, pp. 420-441, $\underline{\text { CrossRef }}$

- Cai, J. and Wei, K.C. (1997) The investment and operating performance of Japanese initial public offerings, Pacific Basin Financial Journal, Vol. 5, pp. 389-417, CrossRef

- Carter, R.B., Dark F. H., and Singh, A.K. (1998) Underwriter Reputation, Initial Return and Long-Run Performance of IPO stocks. The Journal of Finance, Vol. LIII, No.1, CrossRef

- Chan, K., Wang, J. and Wei K.C.J. (2003) Underpricing and long-term performance of IPOs in China, Journal of Applied Corporate Finance, pp. 1-22

- Chen, A. Chen, L.W. and Kao, L (2010) Leverage, liquidity and IPO long-run performance: evidence from Taiwan IPO markets. International Journal of Accounting \& Information Management. Vol. 18, Iss. 1, pp.31-38, CrossRef

- Corhay, A., Teo, S. and Rad, A.T. (2002) The long-run performance of Malaysian initial public offerings (IPO): value and growth effects, Managerial Finance, Vol.28, Issues 2, pp. 52-65, CrossRef

- Drobetz, W., Kammermann, M. and Walchle, U. (2005) Lon-run performance of Initial Public Offerings: The evidence for Switzerland, Schmalenbach Business Review, Vol. 57, pp.253-275

- Durukan, M.B. (2002) The relationship between IPO returns and factors influencing IPO performance: case of Istanbul Stock Exchange, Managerial Finance, Vol. 28, Issues, 2, pp. 18-38, CrossRef

- Gao, N., and Jain B.A. (2011) Founder CEO management and the long-run investment performance of IPO firms. Journal of Banking and Finance, 35, pp. 1669-1682, $\underline{\text { CrossRef }}$

- Goergen, M. Khurshed, A and Mudambi, R. (2007) The long-run performance of UK: can it be predicted?, Managerial Finance, Vol. 33, Iss. 6, pp. 401-419

- How, J., Jelic, R., Saadouni, B., \& Verhoeven, P. (2007) Share allocations and performance of KLSE second board IPOs. Pacific-Basin Finance Journal, 15(3) 292-314, CrossRef

- How, J.C, Ngo, K. and Verhoeven, P. (2011) Dividend initiations and long-run IPO performance, Australian Journal of Management, 36, pp. 267, $\underline{\text { CrossRef }}$

- Jelic, R., Saadouni, B. and Briston, R. (2001) Performance of Malaysian IPOs: Underwriters Reputation and Management Earnings Forecasts. Pacific-Basin Finance Journal, No. 9, pp. 457-486, CrossRef

- Kim, J., Krinsky, I., and Lee, J. (1995) The aftermarket performance of initial public offerings in Korea, Pacific Basin Finance Journal, Vol. 3, pp. 429-448, CrossRef, CrossRef

- Kirkulak, B. (2008) The initial and long-run return of Japanese venture capital backed and non-venture capital backed IPOs, International Journal of Managerial Finance, Vol. 4, Iss. 2, pp. 112-135, CrossRef

- Kooli, M. and Suret, J. (2004) The aftermarket performance of initial public offerings in Canada, Journal of Financial Management. Vol. 14, pp. 47-66, $\underline{\text { CrossRef }}$ 
Nashirah Binti Abu Bakar, Sofian Rosbi

Long Term Performance of Islamic Share Price for Initial Public Offerings (IPOs) in Malaysia: Evidence from Sharia-Compliant Companies Listed on the Malaysian Stock Exchange (2006-2010)

- $\quad$ Lee, P.J, Taylor, S.L. and Walter, T.S. (1996) Australian IPO pricing in the short and long run, Journal of Banking and Finance, 20, pp. 1189-1210, CrossRef

- Levis, M. (1993) The Long-run performance of Initial Public offerings; The U.K. experience 1980-1988, Journal Financial Management, Vol. 22, pp. 28-41, $\underline{\text { CrossRef }}$

- Miller, E.M. (1977) Risk, uncertainty and divergence of opinion, The Journal of Finance, Vol. 32, pp. 1151-1168, CrossRef

- $\quad$ Paudyal, K., Saadouni. B. and Briston, R.J . (1998) Privatisation Initial Public Offering in Malaysia: Initial Premium and Long Term Performance, Pacific-Basin Finance Journal, Vol. 6, No. 5, pp.427-451, CrossRef

- Paudyal, K., Saadouni. B. and Briston, R.J . (1998) Privatisation Initial Public Offering in Malaysia: Initial Premium and Long Term Performance, Pacific-Basin Finance Journal, Vol. 6, No. 5, pp.427-451, CrossRef

- $\quad$ Ritter, J., (1984) The "hot issue" market of 1980, The Journal of Business, Vol. 57, pp.21-240, CrossRef

- Ritter, J.R. (1991) The Long-Run Performance of Initial Public offerings, Journal of Finance, Vol. 46, No. 1, pp. 3-27, CrossRef

- Su, C. and Bangassa, K. (2011) The impact of underwriter reputation on initial returns and long-run performance of Chinese IPOs, Journal of International Financial Markets, Institutions and Money, Vol. 21, pp. 760-791, CrossRef 